\title{
KONTRIBUSI PEMAHAMAN K3 DAN DISIPLIN KERJA TERHADAP KINERJA KARYAWAN PT. BATAMEC SHIPYARD BATAM
}

\section{CONTRIBUTION OF OCCUPATIONAL HEALTH AND SAFETY UNDERSTANDING AND WORK DISCIPLINE ON EMPLOYEE PERFORMANCE OF PT. BATAMEC SHIPYARD BATAM}

\author{
Agnesia Sitinjak $^{1}$, Suryo Hartanto ${ }^{2}$ \\ ${ }^{1.2}$ Fakultas Keguruan dan Ilmu Pendidikan Universitas Riau Kepulauan \\ suryo@fkip.unrika.ac.id
}

\begin{abstract}
Abstrak
Kesehatan dan keselamatan kerja, disiplin kerja merupakan salah satu faktor yang membangun kinerja karyawan. Tujuan penelitian ini adalah untuk mengetahui kontribusi pemahaman Keselamatan dan Kesehatan dan disiplin kerja terhadap kinerja karyawan PT. Batamec Shipyard Batam. Penelitian ini adalah penelitian korelasional, dengan populasi karyawan lapangan PT. Batamec Shipyard sebanyak 433 karyawan, dengan sampel 221 karyawan yang dipilih secara random. Instrumen penelitian menggunakan angketyang telah di uji validitas dan reliabilitas. Hasil penelitian menunjukkan bahwa terdapat kontribusi pemahaman Kesehatan dan Keselamatan Kerja terhadap kinerja karyawan PT. Batamec Shipyard Batam sebesar 4,2\%, kontribusi disiplin kerja terhadap kinerja karyawan PT. Batamec Shipyard Batam sebesar 2,8\%, kontribusi pemahaman Kesehatan dan Keselamatan Kerja dan disiplin kerja secara bersama-sama terhadap kinerja karyawan PT. Batamec Shipyard Batam sebesar 6,9\%. Berdasarkan temuan penelitian ini disimpulkan bahwa pemahaman Kesehatan dan Keselamatan Kerja dan disiplin kerja berkontribusi terhadap kinerja karyawan.
\end{abstract}

Kata kunci:Keselamatan dan Kesehatan Kerja, disiplin dan kinerja.

\begin{abstract}
Occupational Health and Safety, work discipline is one of the factors that build employee performance. The aims of the research is to determine the contribution of Occupational Safety and Health understanding and discipline in work through the performance of PT. Batamec Batam Shipyard's employees. This research is correlational. Population is 443 field employee of PT. Batamec Shipyard with 221 sample, using simple randam sampling technique.Questionnaire is an instrument used in this study who had been on the validity and reliability. The results showed that there is a contribution of Health and Safety understanding, the performance of Batamec Batam Shipyard Company's employees amounted to 4,2\%, a contribution of work discipline on the employees performance of Batamec Batam Shipyard Company amounted to 2,8\%, a contribution safety and health understanding and work discipline on the performance Batam Shipyard Company's employees at 6,9\%. Based on the findings of this study concluded that the Health and Safety understanding and discipline contribute to employee performance.
\end{abstract}

Keywords: Occupational Health and Safety, discipline, performance of work.

\section{PENDAHULUAN}

Undang Undang No.13 Tahun 2013 menyebutkan bahwa tenaga kerja adalah setiap orang yang mampu melakukan pekerjaan guna menghasilkan barang dan atau jasa untuk memenuhi kebutuhan sendiri maupun masyarakat. Karyawan merupakan salah satu faktor penting yang 
dibutuhkan untuk keberhasilan perusahaan, karyawan merupakan kekayaan hidup yang perlu dikembangkan. Oleh sebab itu karyawan harus mendapatkan perhatian khusus dari perusahaan. Di dalam dunia kerja, seorang karyawan akan menggunakan kemampuan terbaik yang dimiliki untuk mengerjakan pekerjaannya dan ketika seseorang mendapatkan hasil yang baik, maka hal tersebut akan menjadi sebuah prestasi dalam pekerjaannya(Hartanto, 2015).Setiap perusahaan selalu mengharapkan karyawannya mempunyai prestasi, karena dengan memiliki karyawan yang berprestasi perusahaan dapat meningkatkan kinerja perusahaannya. Pada perusahaan kinerja karyawan merupakan salah satu penunjang agar kualitas perusahaan menjadi lebih baik.

Dalam proses operasional perusahaan terdapat beberapa masalah terkait dengan karyawan salah satunya adalah menurunnya kinerja karyawan. Berdasarkan survey awal di PT. Batamec Shipyard diperoleh informasi bahwa rendahnya kinerja karyawan diperkirakan ada hubungannya dengan kedisiplinan karyawan dalam proses bekerja. Kinerja karyawan dikatakan rendah dilihat dari kurangnya inisiatif dan kehati-hatian karyawan saat bekerja di lapangan. Inisiatif yang dimaksud adalah karyawan bekerja hanya berdasarkan perintah atasan saja, inisiatif karyawan tidak ada untuk melakukan pekerjaan lain sebelum diperintahkan oleh atasan. Begitu juga dengan kehati-hatian karyawan saat bekerja masih kurang. Ada beberapa karyawan yang hanya bekerja sekedar bekerja tanpa memikirkan resiko terhadap apa yang dilakukan. Biasanya hal ini terjadi pada pekerjaan yang bersifat mendesak (Urgent). Kinerja karyawan juga dapat dilihat pada ketepatan karyawan saat menyelesaikan pekerjaan. Dalam hal ini masih terdapat karyawan yang tidak disiplin dalam menyelesaikan tugasnya karena beberapa faktor tertentu sehingga membuat waktu yang telah ditetapkan terbuang ataupun lebih panjang dari waktu yang telah ditentukan sebelumnya.

Kinerja karyawan dipengaruhi oleh beberapa faktor, Simanjuntak dalam Gusnetti (2014: 2) "kinerja setiap orang dipengaruhi oleh banyak faktor yang dapat digolongkan dalam tiga kelompok yaitu kompetensi individu orang yang bersangkutan, dukungan organisasi dan dukungan manajemen". Suatu kinerja dapat dilihat dari kompetensi karyawan sedangkan kompetensi karyawan dapat dipengaruhi oleh kemampuan dan keterampilan kerja serta motivasi dan kedisiplinan. Kemampuan dan keterampilan kerja ini dapat digolongkan kepada bakat yang dimiliki karyawan yang dipengaruhi oleh kesehatan fisik, pendidikan, serta pengalaman kerja. Berbeda dengan motivasi dan kedisiplinan yang dipengaruhi oleh gaji/ upah, insentif, tantangan, prestasi, dan lingkungan (Gusnetti, 2014: 4). Kualitas kedisiplinan kerja meliputi, datang dan pulang tepat waktu, pemanfaatan waktu untuk pelaksanaan tugas dan kemampuan mengembangkan potensi diri berdasarkan motivasi yang positif. Dewi (2014: 
14) "kinerja karyawan adalah hasil kerja secara kualitas dan kuantitas yang dicapai oleh seorang karyawan dalam melaksanakan tugasnya sesuai dengan tanggung jawab yang diberikan kepadanya". Irham (2010: 2) "kinerja merupakan hasil yang diperoleh oleh suatu organisasi baik organisasi tersebut bersifat profit oriented dan non profit oriented yang dihasilkan selama satu peride waktu", sedangkan Suprihatiningrum dalam Cahyo (2015: 10) "kinerja adalah perbandingan antara penampilan seseorang dengan hasil yang diharapkan". Dalam hal ini kinerja merupakan hasil keterkaitan antara usaha, kemampuan dan persepsi tugas. Berdasarkan penjelasan di atas maka yang dimaksud dengan kinerja karyawan adalah suatu "hasil", yaitu prilaku nyata yang dapat diukur dan ditampilkan setiap orang sebagai prestasi kerja yang dihasilkan oleh karyawan sesuai dengan perannya dalam perusahaan.

Disiplin kerja merupakan salah satu faktor yang mempengaruhi kinerja karyawan. Disiplin yang baik akan mencerminkan besarnya hubungan rasa tanggung jawab karyawan terhadap tugas-tugas yang diberikan oleh perusahaan. Perusahaan berhak menuntut karyawan untuk disiplin bekerja dan melaksanakan tugas-tugas yang diberikan oleh perusahaan, serta berkewajiban untuk memberikan jasa terhadap hasil pekerjaannya. Begitu juga dengan karyawan berkewajiban dalam melakukan tugas-tugas yang diberikan oleh perusahan dan berhak menerima jasa. Disiplin kerja karyawan dapat terlihat dari kehadiran karyawan, ketepatan waktu datang ke lokasi perusahaan, serta ketepatan dalam melaksanakan aturan yang diterapkan. Berdasarkan observasi, diperoleh data rata-rata ketidakhadiran karyawan pada bulan Juni 2015 sebanyak 61\% hadir dan 39\% tidak hadir, sedangkan untuk ketidakhadiran rata-rata pada bulan September 2015 diperoleh 54\% karyawan dan 46\% karyawan yang tidak hadir. Pada kasus ini terjadi peningkatan ketidakhadiran karyawan. Hal ini menunjukan masih banyak karyawan yang tidak berdisiplin untuk melakukan segala aturan yang ditetapkan oleh perusahaan demi kebaikan karyawan. Indah (2014: 182) "disiplin merupakan suatu keadaan tertentu dimana orang-orang yang tergabung dalam organisasi tunduk pada peraturan-peraturan yang ada dengan rasa senang hati”. Rivai dalam Cahyo (2015: 26), Disiplin kerja adalah suatu alat yang digunakan para manajer untuk berkomunikasi dengan pegawai agar mereka bersedia untuk mengubah suatu perilaku serta sebagai suatu upaya untuk meningkatkan kesadaran dan kesedian seseorang mentaati semua peraturan perusahaan dan norma-norma sosial yang berlaku.

Menurut pengertian di atas, disiplin merupakan suatu tindakan karyawan dalam suatu perusahaan yang mengharuskan karyawan untuk tunduk dan mentaati segala peraturanperaturan dan norma-norma sosial yang berlaku dengan rasa senang hati menjalankannya. 
Hasibuan (2008: 193), kedisiplinan adalah kesadaran dan kesediaan seseorang mentaati semua peraturan perusahaan dan norma-norma sosial yang berlaku." Novitasari dalam Anita Sutresna (2013: 9), konsep disiplin kerja dikembangkan dalam dimensi disiplin kerja yaitu penggunaan waktu secara efektif, ketaatan terhadap peraturan yang telah ditetapkan, dan tanggung jawab dalam pelaksanaan tugas”.Berdasarkan penjelasan di atas maka yang dimaksud dengan disiplin kerja adalah suatu sikap, tingkah laku, dan perbuatan yang sesuai dengan peraturan baik tertulis maupun tidak tertulis, dan bila melanggar akan ada sanksi atas pelanggarannya. Disiplin yang baik mencerminkan besarnya tanggung jawab seseorang terhadap tugas-tugas yang diberikan kepadanya.

K3 termasuk salah satu program pemeliharaan yang ada di perusahaan sebagai salah satu upaya dalam menghindari kecelakaan kerja, kerusakan alat dan gangguan terhadap produk. Maka pemahaman tentang K3 oleh karyawan merupakan salah satu cara untuk mencapai tujuan memperkecil terjadinya kecelakan kerja dan kerugian lain yang ditimbulkan.Indah (2014: 315) "keselamatan kerja merupakan salah satu faktor yang harus dilakukan selama bekerja". Tujuan keselamatan kerja yang efektif di perusahaan adalah mencegah kecelakaan atau cidera yang terkait dengan pekerjaan. Yani (2014: 157) "kesehatan kerja merupakan suatu kondisi yang bebas dari gangguan secara fisik dan psikis yang disebabkan oleh lingkungan kerja”. Gangguan fisik yaitu gangguan secara jasmani yang terlihat secara nyata dari tubuh karyawan yang disebabkan oleh keadaan ataupun lingkungan kerja sedangkan gangguan psikis itu berhubungan dengan gangguan keadaan jiwa karyawaan yang tidak terlihat secara langsung namun gangguan ini disebabkan oleh lingkungan kerja.

Tabel 1. Data Kecelakaan Kerja Karyawan PT. BSB Tahun 2010-2014

\begin{tabular}{ccccc} 
No & Tahun & $\begin{array}{c}\text { Human } \\
\text { Error }\end{array}$ & $\begin{array}{c}\text { Tool } \\
\text { Error }\end{array}$ & Jumlah \\
\hline 1 & 2010 & 60 & 9 & 69 \\
\hline 2 & 2011 & 67 & 9 & 76 \\
\hline 3 & 2012 & 30 & 8 & 38 \\
\hline 4 & 2013 & 68 & 5 & 73 \\
\hline 5 & 2014 & 50 & 5 & 55 \\
\hline \multicolumn{2}{c}{ TOTAL } & 275 & 36 & 311 \\
\hline
\end{tabular}

Sumber: PT. BSBatam, 2010-2015

Terkait dengan angka kecelakaan kerja, berdasarkan data Tabel 1. Tahun 2010-2014 kecelakaan kerja terbesar pada PT. Batamec Shipyard Batam disebabkan oleh kesalahan manusia (Human Error). Melalui wawancara salah satu karyawan PT. Batamec Shipyard diperoleh informasi bahwa pemahaman K3kepada karyawan sudah sering diberikan salah satunya melalui breafing di awal jam kerja dengan durasi waktu kurang lebih 10 menit pada 
departemen masing-masing, namun hal ini masih kurang apalagi ditambah dengan rendahnya kepedulian beberapa karyawan untuk menerapakan keselamatan dan kesehatan kerja, contohnya adalah masih ditemukan karyawan yang tidak menggunakan sarung tangan, sepatu maupun wearpack atau setandar keselamatan lain yang telah ditetapkan oleh perusahaan.Dalam pemahaman umum, K3 merupakan suatu ilmu pengetahuan dan penerapannya dalam usaha mencegah kemungkinan terjadinya kecelakaan dan penyakit akibat kerja. (Armanda dalam Bobby et al, 2013: 431). K3tidak dapat dipisahkan dengan proses produksi baik jasa maupun industri. Definisi tersebut menunjukan bahwa K3ditandai dengan "mencegah", yaitu mencegah resiko kecelakaan yang merupakan upaya mengurangi beban dalam kerja supaya selamat dari kecelakaan bekerja. Occupational health and safety is conditions and factors that affect, or could affect, the health and safety of employees or other workers (including temporary workers and contractor personnel), visitors, or any other person in the workplace. (British Standar Internasional, 2007: 5). Dengan demikian yang dimaksud dengan pemahaman $\mathrm{K} 3$ adalah segala sesuatu yang berhubungan dengan pemahaman K3sebagai segala upaya untuk mengendalikan risiko yang berkaitan dengan kegiatan kerja guna terciptanya tempat kerja yang aman, efisien dan produktif. Berdasarkan temuan masalah yang telah dijabarkan diatas maka tujuan penelitian ini adalah untuk mengetahui kontribusi pemahaman Keselamatan dan Kesehatan dan disiplin kerja terhadap kinerja karyawan di PT. Batamec Shipyard Batam.

\section{METODOLOGI}

Jenis penelitian ini adalah korelasional. Siregar (2014: 7), penelitian korelasional adalah penelitian yang bertujuan untuk mengetahui hubungan antara dua variabel atau lebih. Penelitian korelasi ini bersifat assosiatif yang merupakan dugaan tentang adanya hubungan antar variabel yang diambil dalam populasi tersebut. Penelitian ini menggunakan analisis regresi untuk mengetahui hubungan fungsional antara variabel responden dan prediktor (Gunawan, 2013: 15). Regresi yang digunakan dalam penelitian ini adalah regresi berganda.

Populasi dalam penelitian ini adalah seluruh karyawan lapangan PT. Batamec Shipyard sebanyak 433 karyawan. Penentuan ukuran sampel menggunakan rumus slovin yaitu sebanyak 221 karyawan. Instrumen penelitian ini menggunakan angket yang telah diuji tingkat validitas dan reliabilitasnya. Pengujian validitas instrumen ini menggunakan rumus Korelasi Product Moment, sedangkan pengujian reliabilitas instrumen angket dilakukan dengan Alpha Cronbach.Berdasarkan perhitungan, didapat $r_{11}=0,905$ untuk angket 
pemahaman K3, $\mathrm{r}_{11}=0,925$ untuk angket disiplin kerja dan $\mathrm{r}_{11}=0,929$ untuk angket kinerja karyawan.

\section{HASIL DAN PEMBAHASAN}

Berdasarkan hasil peneliti berikut disampaikan distribusi data penelitian pada masing-masing variabel:

Tabel 2. Distribusi Data Penelitian

\begin{tabular}{|c|c|c|c|}
\hline No Deskripsi & K3 & $\begin{array}{l}\text { Disiplin } \\
\text { kerja }\end{array}$ & Kinerja \\
\hline 1. $N$ & 221 & 221 & 221 \\
\hline 2. Mean & 72,10 & 82,61 & 75,03 \\
\hline 3. Std.Deviation & 5,719 & 5,921 & 8,405 \\
\hline 4. Minimum & 60 & 70 & 57 \\
\hline 5. Maximum & 86 & 96 & 92 \\
\hline 6. Sum & 15935 & 18257 & 16581 \\
\hline
\end{tabular}

Berdasarkan data Tabel 2. Data K3karyawan diperoleh angka rata-rata 72,10, standar deviasi 5,719 , serta skor terendah adalah 60 dan skor tertinggi adalah 86. Secara umum pemahaman K3 pada karyawan PT. Batamec Shipyard Batam tergolong baik. Hal ini dapat dilihat dari deskripsi data angket yang disebarkan,perhitungan yang diperoleh dari hasil derajat pencapaian pemahaman K3 sebesar 81,93\%. Untuk distribusi data kedisiplinan karyawan diperoleh rata-rata 82,61, standar deviasi 5,921, serta skor terendah adalah 70 dan skor tertinggi adalah 96. Secara umum disiplin kerja pada karyawan PT. Batamec Shipyard Batam tergolong sangat baik. Hal ini dapat dilihat dari deskripsi data angket yang disebarkan. Berdasarkan perhitungan diperoleh hasil pencapaian disiplin kerja sebesar 93,87\%. Untuk data kinerja diperoleh rata-rata 75,03, standar deviasi 8,405, serta skor terendah adalah 57 dan skor tertinggi adalah 92. Secara umum kinerja karyawan pada karyawan PT. Batamec Shipyard Batam tergolong cukup baik. Hal ini dapat dilihat dari deskripsi data angket yang disebarkan. Berdasarkan perhitungan diperoleh hasil pencapaian kinerja karyawan sebesar $75,02 \%$.

Untuk mengetahui kontribusi pemahaman K3 dan disiplin kerja terhadap kinerja karyawan PT. Batamec Shipyard Batam, dilakukan uji hipotesis sebagai berikut:

\begin{tabular}{llll}
\hline & & $\mathrm{X}_{1}$ & $\mathrm{Y}$ \\
\hline \multirow{2}{*}{$\mathrm{X}_{1}$} & Pearson Correlation & 1 & $.207^{* *}$ \\
\cline { 2 - 4 } & Sig. (2-tailed) & .002 \\
\cline { 2 - 4 } $\mathrm{N}$ & 221 & 221 \\
\hline \multirow{2}{*}{$\mathrm{Y}$} & Pearson Correlation & $.207^{* *}$ & 1 \\
\cline { 2 - 4 } & Sig. (2-tailed) & .002 & 221 \\
\cline { 2 - 4 } & $N$ & 221 & \\
\hline
\end{tabular}


Perhitungan uji hipotesis pertama diperoleh $r_{x 1 y}=0,207$. Besar hubungan termasuk kategori lemah, yaitu pemahaman K3 memiliki hubungan yang lemah dengan kinerja karyawan. Berdasarkan penghitungan di atas uji signifikan diperoleh sig $=0,002<\alpha=0.025$. Berdasarkan tabel distribusi t (Riduwan 2009: 359) nilai $\mathrm{t}_{\text {tabel }}$ dengan $\mathrm{dk}=\mathrm{n}-2=221-2=$ 219 dan taraf signifikan $\alpha=0,05$ adalah 1,960. Kriteria pengujian adalah $\mathrm{t}_{\text {hitung }}>\mathrm{t}_{\text {tabel }}$ maka $\mathrm{H}_{0}$ ditolak. Nilai $t_{\text {hitung }}=3,067$, sehingga keputusan Ho ditolak, artinya terdapat korelasi antara pemahaman K3 terhadap kinerja karyawan PT. Batamec Shipyard Batam. Selanjutnya perhitungan kontribusi variabel $\mathrm{X}_{1}$ terhadap variabel $\mathrm{Y}$ diperoleh sebesar 4,2\%.

Pengujian hipotesis kedua menggunakan korelasi parsial. Hasil perhitungan dapat dilihat sebagai berikut:

\begin{tabular}{llll}
\hline & & $\mathrm{X}_{2}$ & $\mathrm{Y}$ \\
\hline \multirow{2}{*}{$\mathrm{X}_{2}$} & Pearson Correlation & 1 & $.169^{*}$ \\
\cline { 2 - 4 } & Sig. (2-tailed) & & .012 \\
\cline { 2 - 3 } & $\mathrm{N}$ & 221 & 221 \\
\hline $\mathrm{Y}$ & Pearson Correlation & $.169^{*}$ & 1 \\
\cline { 2 - 4 } & Sig. (2-tailed) & .012 & \\
\cline { 2 - 3 } & $\mathrm{N}$ & 221 & 221 \\
\hline \multirow{2}{*}{$*$. Correlation is significant at the 0.05 level (2-tailed). }
\end{tabular}

Perhitungan uji hipotesis kedua diperoleh $r_{x 2 y}=0,169$. Besar hubungan termasuk kategori sangat lemah, yaitu disiplin kerja memiliki hubungan yang sangat lemah dengan kinerja karyawan. Berdasarkan penghitungan di atas uji signifikan diperoleh sig $=0,012<\alpha=$ 0,025. Berdasarkan tabel distribusi t (2009: 359) nilai $\mathrm{t}_{\text {tabel }}$ dengan $\mathrm{dk}=\mathrm{n}-2=221-2=219$ dan taraf signifikan $\alpha=0,05$ adalah 1,960. Kriteria pengujian adalah $t_{\text {hitung }}>t_{\text {tabel }}$ maka $\mathrm{H}_{0}$ ditolak. Nilai $t_{\text {hitung }}=2,448$, sehingga keputusan Ho ditolak, artinya terdapat korelasi antara disiplin kerjaterhadap kinerja karyawan PT. Batamec Shipyard Batam. Selanjutnya perhitungan kontribusi variabel $\mathrm{X}_{2}$ terhadap variabel diperoleh sebesar $2,8 \%$.

Pengujian hipotesis ketiga menggunakan korelasi ganda. Hasil perhitungan dapat dilihat sebagai berikut:

\begin{tabular}{|c|c|c|c|c|}
\hline$\overline{\text { Model }}$ & $\mathrm{R}$ & R Square & $\begin{array}{l}\text { Adjusted R } \\
\text { Square }\end{array}$ & $\begin{array}{l}\text { Std. Error of the } \\
\text { Estimate }\end{array}$ \\
\hline
\end{tabular}




\begin{tabular}{lllll}
\hline 1 & $.262^{\mathrm{a}}$ & .069 & .060 & 8.149 \\
\hline
\end{tabular}

Berdasarkan data di atas menunjukan nilai koefisien ganda sebesar 0,262. Besar hubungan termasuk kategori lemah, yaitu pemahaman K3 dan disiplin kerja secara bersama-sama memiliki hubungan yang lemah dengan kinerja karyawan. Signifikan hubungan antara variabel bebas dan variabel terikat secara simultan digunakan untuk menguji signifikan atau tidaknya hubungan lebih dari satu variabel yang diuji menggunakan uji F. Hasil uji signifikan koefisien korelasi secara simultan dapat dilihat pada data berikut:

\begin{tabular}{lllllll}
\hline Model & Sum of Squares & Df & Mean Square & F & Sig. \\
\hline \multirow{2}{*}{1} & Regression & 1066.109 & 2 & 533.055 & 8.028 & $.000^{\mathrm{b}}$ \\
\cline { 2 - 7 } & Residual & 14475.728 & 218 & 66.402 & & \\
\cline { 2 - 6 } & Total & 15541.837 & 220 & & & \\
\hline
\end{tabular}

Tabel di atas menunjukan bahwa diperoleh uji signifikan (sig) $=0,000<\alpha=0,025$. Berdasarkan data diperoleh $\mathrm{F}_{\text {hitung }}$ sebesar 8,028 sedangkan $\mathrm{F}_{\text {tabel }}$ menurut Riduwan (2009: 365) adalah 3,04. $F_{\text {hitung }}>F_{\text {tabel }}$ sehingga dapat disimpulkan bahwa ada hubungan yang signifikan secara bersama-sama antara variabel bebas dan variabel terikat.Selanjutnya perhitungan kontribusi variabel $\mathrm{X}_{1}$ dan $\mathrm{X}_{2}$ terhadap variabel $\mathrm{Y}$ yaitu sebesar 6,9\%.

Berdasarkan hasil analisa data dan perhitungan korelasi diperoleh hasil yang menyatakan terdapat kontribusi pemahaman K3 terhadap kinerja karyawan PT. Batamec Shipyard yaitu sebesar 4,2\%. Maksudnya adalah pemahaman K3 memberikan sumbangan untuk menentukan kinerja karyawan sebesar 4,2\%. Aspek-aspek yang diukur pada pemahaman K3 seperti pemahaman penggunaan peralatan kerja dan pemahaman kesehatan area kerja merupakan hal-hal yang berkenan pada diri karyawan dalam proses bekerja. Karyawan yang memiliki pemahaman akan menunjukan cara bekerja yang baik. Kemampuan pemahaman yang dimiliki karyawan akan menjadikannya memiliki keinginan-keinginan tertentu termasuk dalam hal pencapaian kinerja yang baik. Sehingga karyawan dapat diketahui memiliki pemahaman K3 apabila karyawan dapat mengurangi kemungkinan terjadinya kecelakaan kerja. Pernyataan ini sesuai dengan pendapat Cintya (2014: 5) menyebutkan bahwa pemahaman K3pada dasarnya mencari dan mengungkapkan kelemahan yang memungkinkan terjadinya kecelakaan kerja. Sementara itu Grisma (2013) mengatakan Pemahaman K3 dapat berfungsi apabila dilakukan dengan mengungkapkan sebab-akibat suatu kecelakaan dan meneliti apakah pengendalian secara cermat dilakukan atau tidak. Bagi 
karyawan seharusnya pemahaman K3 adalah ilmu dasar yang harus sudah dipahami agar saat bekerja tidak terjadi kecelakaan kerja. Dengan memiliki pemahaman K3, maka karyawan akan bekerja dengan hati-hati berdasarkan aturan yang berlaku di perusahaan. Sehingga dapat memperoleh kinerja yang memuaskan.

Berdasarkan hasil analisa data dan perhitungan korelasi diperoleh hasil yang menyatakan terdapat kontribusi disiplin kerja terhadap kinerja karyawan yaitu sebesar 2,8\%. Maksudnya adalah disiplin kerja memberikan sumbangan untuk menentukan kinerja karyawan sebesar 2,8\%. Aspek-aspek yang diukur pada disiplin kerja seperti kewajiban dan tanggung jawab merupakan hal-hal yang berkenan pada diri karyawan dalam proses bekerja. Karyawan yang memiliki tanggung jawab yang tinggi akan menunjukan kinerja yang baik. Dengan adanya tanggung jawab karyawan akan mematuhi segala peraturan yang ada untuk pencapaian suatu kinerja. Penting bagi karyawan untuk selalu hadir dan tidak meninggalkan pekerjaannya, karena dengan minimnya tingkat ketidakhadiran dapat membuat karyawan tersebut bertanggung jawab atas setiap pekerjaan yang diberikan oleh atasan. Pernyataan ini sesuai dengan pendapat yang disampaikan oleh Cahyo (2014: 66) menyatakan disiplin kerja sebagai suatu sikap menghormati, menghargai, patuh, dan taat terhadap peraturan-peraturan yang berlaku baik yang berlaku secara tertulis maupun tidak tertulis serta sanggup menjalankannya.

Berdasarkan hasil analisa data dan perhitungan korelasi diperoleh hasil yang menyatakan terdapat kontribusi pemahaman K3 dan disiplin kerja terhadap kinerja karyawan yaitu sebesar 6,9\%. Maksudnya adalah pemahaman K3 dan disiplin kerja secara bersamasama memberikan sumbangan untuk menentukan kinerja karyawan sebesar 6,9\%. Aspekaspek yang diukur dalam kinerja karyawan seperti kualitas, kuantitas, keandalan, dan sikap merupakan hal-hal yang terkait dalam proses kerja. Karyawan yang menunjukan kinerja yang positif seperti kualitas kerja, maka dapat dilihat saat proses kerja karyawan bekerja dengan hati-hati dan selalu menggunakan APD (alat pelindung diri) untuk mencapai hasil yang baik dan tepat waktu. Kinerja karyawan dapat dilihat dari perilaku nyata saat berkerja. Seperti yang dikatakan Ryska (2013: 12) "kinerja merupakan perilaku nyata yang ditampilkan setiap orang sebagai prestasi kerja yang dihasilkan oleh karyawan sesuai dengan perannya dalam perusahaan”. Kinerja karyawan yang baik tercapai jika karyawan memiliki perilaku nyata dalam melaksanakan tanggung jawabnya. Hal ini juga didukung oleh pendapat Grisma (2013: 
18) kinerja karyawan menunjuk pada kemampuan karyawan dalam melaksanakan keseluruhan tugas-tugas yang menjadi tanggung jawabnya.

Dalam penelitian ini kontribusi yang diberikan oleh Pemahaman K3 dan disiplin kerja terhadap kinerja karyawan memiliki angka yang kecil. Namun walaupun angka nya kecil, angka tersebut memiliki hubungan terhadap kinerja karyawan karena variabel bebas pada penilitian ini merupakan salah satu bagian kecil dari yang mempengaruhi kinerja karyawan. Untuk itu karyawan tetap perlu memahami K3 dan menerapkan disiplin kerja supaya kinerja karyawan dapat lebih baik.

\section{KESIMPULAN}

Berdasarkan hasil penelitian yang telah dilakukan, maka dapat disimpulkan bahwa terdapat kontribusi pemahaman K3terhadap kinerja karyawan PT. Batamec Shipyard Batam sebesar 4,2 \%. Terdapat kontribusi disiplin kerja terhadap kinerja karyawan PT. Batamec Shipyard Batam sebesar 2,8 \%, dan Terdapat kontribusi pemahaman K3 dan disiplin kerja secara bersama-sama terhadap kinerja karyawan PT. Batamec Shipyard Batam sebesar 6,9\%.

\section{REFERENSI.}

Anita Sutresna, S.K (2013). Pengaruh Etos Kerja dan Disiplin Kerja terhadap Kinerja Pegawai (Studi pada Aparat Pemerintahan Kecamatan Baregbeg Kabupaten Ciamis). Skripsi. Ciamis: Fakultas Manajemen Universitas Galuh. Diunduh dari http://www.unigal.ac.id/ejurnal/. Pada tanggal 09 oktober 2015.

Bobby, Rocky Kani., R. J. M. Mandagi., J. P. Rantung., et al. (2013). K3pada Pelaksanaan Proyek Konstruksi (Studi Kasus: Proyek PT. Trakindo Utama). Jurnal elektronik sipil volume 01 nomor 06 Mei 2013. Diunduh dari http://ejournal.unsrat.ac.id/index/. Pada tanggal 18 September 2015.

British Standards Internasional. 2007. Occupational Health and Safety Management SystemRequirements. OHSAS.

Cahyo, A. Nugroho. (2015) Pengaruh Gaya Kepemimpinan dan Disiplin Kerja tehadap Kinerja Pegawai Dinas Pariwisata DIY. Skripsi. Yogyakarta: Fakultas Ekonomi Universitas Negeri Yogyakarta. Dinduh dari http://eprints.uny.ac.id/. Pada tanggal 01 Oktober 2015.

Gunawan, M. Ali. 2013. Statistika untuk Penelitian Pendidikan. Yogyakarta: Pazama Publishing.

Gusnetti. (2014). Faktor - Faktor yang Mempengaruhi Kinerja Karyawan pada PT. Garuda Indonesia. Jurnal elektronik ilmu administrasi volume 01 nomor 0202 Oktober 2014. Diunduh dari http://download.portalgaruda.org/. Pada tanggal 15 September 2015.

Hasibuan, S.P. Malayu. 2008. Manajemen Sumber Daya Manusia. Edisi Revisi. Jakarta: PT. Bumi Aksara. 
Hartanto, S. (2015). KOMPARASI PEMAHAMAN GEOMETRIS KARYAWAN LULUSAN SMK DAN SMA TERHADAP PROSES MACHINING CNC DI PT. TOMOE VALVE BATAM, 4(2), 34-42. Retrieved from http://journal.unrika.ac.id/index.php/jurnalphythagoras/issue/view/20

Indah, H. Puji. 2014. Buku Praktis Mengembangkan SDM. Jogjakarta: Laksana.

Irham Fahmi. 2010. Manajemen Kinerja Teori dan Aplikasi. Bandung: Alfabeta.

Siregar, Sofyan. 2014. Metode Penelitian Kuantitatif. Jakarta: Kencana

Yani. 2012. Manajemen Sumber Daya Manusia. Jakarta: Mitra Wacana Media Noor, Juliansyah. 2013. Metodologi Penelitian. Jakarta: Kencana. 